\title{
WAYS OF COPING WITH AIDS: OPINION OF MOTHERS WITH HIV CHILDREN ${ }^{1}$
}

\author{
Richardson Augusto Rosendo da Silva ${ }^{2}$ \\ Vera Maria da Rocha ${ }^{3}$ \\ Rejane Marie Barbosa Davim ${ }^{4}$ \\ Gilson de Vasconcelos Torres ${ }^{5}$
}

Silva RAR, Rocha VM, Davim RMB, Torres GV. Ways of coping with AIDS: opinion of mothers with HIV children. Rev Latino-am Enfermagem 2008 março-abril; 16(2):260-5.

The research aims at identifying strategies of coping with AIDS used by mothers of HIV positive children to live better with their children's disease. The method used was a descriptive qualitative study. Thirtythree structured interviews were conducted with HIV positive women voluntaries and registered as users in the clinic of the public hospital of reference for the treatment of AIDS in Natal/RN. For data analysis, the method used was thematic content analysis. From the analysis, prevalent categories regarding forms of facing AIDS came up, they were: overprotection and fear; donation; hope; religious belief; underestimation of HIV; hiding the diagnosis; and resignation. This study shows that despite AIDS limitations and barriers, relatives develop strategies that make it possible to face every day problems and live better with it.

DESCRIPTORS: HIV; acquired immunodeficiency syndrome; HIV seropositivity; mothers; coping behavior

\section{FORMAS DE ENFRENTAR EL SIDA: OPINION DE MADRES CON NIÑOS SEROPOSITIVOS}

El estudio tuvo como objetivo identificar estrategias de madres con niños seropositivos para enfrentar el sida; de tal forma que puedan convivir con la enfermedad de sus hijos. El método utilizado fue la investigación cualitativa y descriptiva. Las respuestas fueron obtenidas de treinta y tres entrevistas realizadas con mujeres seropositivas voluntarias y registradas en el servicio ambulatorio de un hospital público especializado en tratamiento de SIDA de Natal/RN. Para ello, fue utilizada la técnica de análisis de contenido, específicamente por temática. Del análisis, surgieron categorías con relación a las formas de enfrentar el SIDA: sobreprotección y miedo, donación, negación y poca importancia dada al HIV, ocultando la enfermedad, resignación, religión y esperanza. Este estudio mostró que, a pesar de las limitaciones y barreras debidas al SIDA, Ios familiares desarrollan estrategias que permiten enfrentar el cotidiano y convivir mejor con esta experiencia.

DESCRIPTORES: VIH; síndrome de inmunodeficiencia adquirida; seropositividad para VIH; madres; adaptación psicológica

\section{FORMAS DE ENFRENTAMENTO DA AIDS: OPINIÃO DE MÃES DE CRIANÇAS SOROPOSITIVAS}

O estudo teve como objetivo identificar as estratégias de enfrentamento, utilizadas por mães de crianças soropositivas, para melhor conviverem com a doença dos filhos. O método utilizado foi a pesquisa qualitativa descritiva. As falas foram retiradas de trinta e três entrevistas estruturadas com mulheres soropositivas voluntárias, inscritas no ambulatório de um hospital público de referência para o tratamento da AIDS em Natal, RN. Utilizou-se a técnica de análise de conteúdo, em especial, a temática. Da análise, emergiram categorias prevalentes em relação às formas de enfrentamento da AIDS, ou seja: superproteção e medo, doação, negação e subestimação do HIV, ocultação da doença, resignação, religião e esperança. Este estudo revelou que, apesar dos limites e barreiras impostas pela AIDS, os familiares desenvolvem estratégias que possibilitam enfrentar o cotidiano e conviver melhor com essa experiência.

DESCRITORES: HIV; síndrome de imunodeficiência adquirida; soropositivade para AIDS; mães; adaptação psicológica

${ }^{1}$ Article extracted from Master's Thesis; ${ }^{2}$ RN, Doctoral Student, Rio Grande do Norte Federal University, Brazil, e-mail: rirosendo@yahoo.com.br; ${ }^{3}$ Physiotherapist, PhD in Education, e-mail: rvera@digi.com.br; ${ }^{4} \mathrm{RN}, \mathrm{PhD}$ in Health Sciences, Faculty, e-mail: rejanemb@uol.com.br; ${ }^{5} \mathrm{RN}, \mathrm{PhD}$ in Nursing, Adjunct Professor, email: gvt@ufrnet.br. Rio Grande do Norte Federal University, Brazil 


\section{INTRODUCTION}

$\boldsymbol{H}_{\text {IV/AIDS epidemic is a worldwide reality and }}$ it is one of the most serious public health problems. In Brazil, from the beginning of the 80 's to $2006,433,067$ cases of AIDS have been reported by the Ministry of Health. Os this total, 142,138 refer to female adults, and 16,071 to children below 13 . These results confirm the current situation of the epidemic in Brazil, characterized by "heterosexualization", "femininization", and increase in vertical transmission ${ }^{(1)}$.

With the increase in the number of cases of AIDS and the consequent increase in the risk of vertical transmission of HIV, an increased number of children and newly born are affected by this virus.

Although these figures are concerning, they do not reflect well the devastating effect of this disease in the life of seropositive people. We know that the HIV/AIDS diagnosis is an event of personal impact, and it is an event in the story of families and in their experience with the disease. Another important marker is the fact that AIDS imposes new habits such as: frequent visits to doctors, undergoing long treatment, medication intake, undergoing several examinations, difficulty in dealing with the disease, as well as changes in family life ${ }^{(2)}$.

Children with AIDS may experience extreme psychological suffering, since, in addition to limiting their everyday activities such as: playing, running, and expressing themselves because of the physical impairments caused by opportunistic diseases, they can also be overprotected or discriminated by people around them and those taking care of them (3), especially mothers, since they have to coordinate treatment and everyday activities.

These mothers tend to face new challenges (4) such as: the diagnoses, the start and follow-up of school, adherence to a long-term complex treatment, the arrival of puberty and the start of sex life.

Living everyday with children with HIV makes mothers adapt to a new reality and develop coping strategies for managing stressors, for the physical, psychological and social welfare of children.

Research shows that the adaptation of families to seropositivity may be an important factor to determine the adaptation of children with HIV/AIDS (5). Studies have shown that several families develop coping strategies geared to normalization, health maintenance, social insertion and improvement in quality of life of seropositive children ${ }^{(6)}$. The present study was conducted in this context, with the objective of identifying coping strategies used by mothers of seropositive children to live better with their children's disease.

The relevance of the research is justified because of the need for greater knowledge on the psychological and social aspects that affect this group of seropositive people to structure care models geared to mothers/care takers of HIV children for full and multidisciplinary attention in HIV/AIDS.

\section{METHODS}

Descriptive survey with a qualitative approach, developed in the outpatient clinic of the tertiary Hospital Giselda Trigueiro (HGT) a reference in the treatment of AIDS in the city of Natal-RN, Northeast Region in Brazil.

Target population of the study was made up by HIV mothers with seropositive children seen at HGT. For inclusion in the study the following criteria were considered: a) voluntary participation; b) give informed consent; c) confirmed HIV medical diagnoses; d) being over 18; e) having at least one child with confirmed HIV diagnoses; f) use HGT outpatient clinic and having a medical appointment on the day of interview. Exclusion factors were: a) not giving informed consent; b) mother with children below 18 months, with unconfirmed diagnoses and, c) mothers that, voluntarily, wanted to be away during collection.

Interviews have been conducted with 33 young mothers with HIV children with ages ranging from 20 and 36 years old, and mean age was 28, predominant age group was from 26 to 30 (52\%). Regarding schooling, a greater proportion of women had not finished elementary school, accounting for $67 \%$ of the interviewees; $21 \%$ of the participants had finished elementary school, and only $12 \%$ had incomplete high school. Predominant family income in the studied sample was one minimum wage $(73 \%$ of the participants), and $27 \%$, received up to 2 minimum wages. Prevalent form of transmission of the participants, according to them, was heterosexual transmission from a stable partner $(88 \%)$. Twelve per cent of the women got the virus through the use of injection drugs. The greatest concentration of diagnoses occurred from 2000 to $2002(28 \%)$. 
As a collection instrument, an interview script was used with structured questions, previously assessed by expert researchers on the issue, and validated through a pilot study.

The project has been approved by the Ethical Research Committee of the Federal University of Rio Grande do Norte, under \# 142/04. All mothers who accepted to take part in the research gave their informed consent, after they were explained about the objectives of the survey. To protect the identity of participants, fictional names of women have been used in the quotations of statements.

A process of data collection was started between March and June 2005 with recorded interviews and, later, fully transcribed and grouped into categories that came up from the speech of participants, following content analysis, especially, the thematic $^{(7)}$.

Results are presented and discussed considering the analysis of the interviews, with categories from the speeches listed according to questionnaires performed.

\section{RESULTS AND DISSCUSSION}

\section{Coping strategies of mothers regarding HIV/AIDS}

According to the objectives of the present study, in this stage we will present some categories that enabled to understand some strategies used by mothers of seropositive women to live better with their children's disease. Coming from the speech of mothers, according to guiding questionnaires, six categories are highlighted: overprotection and fear; disease; HIV denial and underestimation; hiding the disease; resignation; religion and hope.

- Overprotection and fear

We have identified in the speech of mothers that the everyday life of seropositive mothers, frequently marked by the presence and risk of opportunistic infections, leads to a feeling of overprotection. In addition to that, there is also the fear of children suffering from violence because they are seropositive. The disease appears as a constant threaten and fear, not only fear of the disease and death, but also of the expected prejudice and the uncertainty regarding the future, made clear by this speech:
Mothers of children with AIDS, we have to protect them all the time, because they get sick much more often (Paula).

I protect my child too much, because I fear she will suffer some kind of violence because she has this disease (Isabel).

I'm afraid my child will be abandoned, how will he face the world? What will become of him...He is completely dependent (Maria).

Therefore, it was observed that mothers reacted with excessive concern, with phobic and controlling behavior, becoming overprotective with children, preventing them from taking part and cooperating in their treatment. The presence of overprotection and unsuitable behavior reinforce the thesis of inability of mothers in dealing with their children, due to feelings and beliefs related with AIDS.

Concern of parents regarding uncertainty about the future of children, feeling guilty, and unsolved angry may determine an overprotective behavior. This same feeling, that shows excessive kindness and patience, was made clear in studies conducted with mothers of children with chronic diseases. Despite inevitable separation in some hospital situations, in the universe of seropositive people, there is permanently the fear of getting sick and dying (8-11).

AIDS is the most recent representation of the evil of social imagination of the Western and appears in the public space as an announced death ${ }^{(12)}$.

AIDS is a fatal disease, it is a sentence of future death...I fear my child will die, I won't be able to stand it (Mônica).

Overprotection of mothers and greater dependence of children increase emotional and behavior problems. When children-mothers interaction is inappropriate, children present greater risks of delays and/or difficulties in development, and may present social, cognitive and linguistic limitations, and even negligence ${ }^{(13)}$.

- Total dedication

By the way they behave regarding the feeling of total dedication, mothers showed some guilty because of the children's disease. However, it was observed that the condition of being seropositive is not highlighted as a concern. In their speech it was possible to see that priority is the care of their children's health, and to that end, they use all their potential, as indicated by the following statements: 
I try to satisfy my son completely, I believe I do that to soothe my guilty (Joana).

After this disease I had to reorganize my time (Simone).

Taking care of my son comes first; it takes up all my time and energy, I may forget my appointment but his appointment I don't forget (Érica).

I force my daughter to follow strictly the treatment the doctor gives her... without this treatment, she may die (Maria).

It was noticed in the mothers' statements that if they changed their routine, based on taking care of their children full time, they could deal with the children's disease better.

This new routine takes up great part of the time of care mothers, they are either controlling the symptoms, dedicating to treatment and preventing and facing crises. Total dedication tends to make feelings of guilty, fear, and uncertainty in the future, frequent in the everyday lives of mothers of HIV children, disappear.

For mothers, anti-retroviral medication is essential, and it was even the responsible for maintaining life, because without the medication, children would not survive. From then on, mothers give themselves totally to make children comply with treatment.

- Denial and Underestimation of HIV

Because AIDS is a disease still associated with death, a way to survive with diagnoses of having HIV and coping with the disease is putting this condition on the background, not letting it take a great part in their lives ${ }^{(14)}$. Thinking excessively in AIDS was reported by interviews as a way to give in to the disease. Giving in to the disease is refused, through denial by some, and underestimation by others, trying to reestablish normality to cope and deal with the disease better.

On the speech of interviewees we could notice that they are aware that they have AIDS, that their children have the virus, however, they avoid coping with this reality, which in addition to being painful, imposes a new direction to their lives, as can be seen in the following statements:

I tell my son we have the virus but that he should not think about that, and then he is relieved (Fernanda).

It is just a matter of taking the cocktail, with a low viral load you keep a normal life. Now, if we think we are going to die from AIDS, then you really die (Camila).

Everything is new to me... it took me a while to accept and look for help (Carla).
This denial may be an escape from reality, as an attempt of individuals to adjust to a new situation. Thus, while this process occurs, people stop looking for help for their emotional and physical health, decreasing their support network. This is important because strategies that involve avoidance or denial of infection are described as most commonly associated with psychological distress and low indexes of quality of life ${ }^{(15)}$.

When people discover they have an incurable disease, they experience several feelings that lead to conflicts, which are common and are part of the coping mechanisms for their insecurity. Usual feelings are: denial, anger, bargain, depression, isolation, and acceptance, and each individual experience these changes uniquely, with different sequence and intervals. Having AIDS is not only having an incurable disease, such as cancer, because in addition to the real spectrum of the disease, there is also a great social stigma ${ }^{(16)}$.

- Hiding the disease

Not telling children they have the disease and not sharing their diagnoses with other people is a way of coping with AIDS, it is a way out of problems from a seropositive situation, as identified by this speech:

Nobody at home knows I have AIDS. When I came back from maternity I did not nurse my child, I made up my milk was weak. My mother said some things, but I pretended and I didn't say anything (Priscila).

Silence regarding the infection, in addition to preventing sharing it with other people who could help coping with the disease, hinders adherence to treatment both due to the difficulty in using medications in the presence of others, and to have to explain some procedures, such as not breastfeeding. This silence may be a way of coping with the disease ${ }^{(17)}$.

This was mentioned by Patrícia:

After I receive medication in the hospital, as soon as I get home I take out all the labels so my son does not read them and my parents don't get suspicious. I always tell them they are vitamins (Vera).

... I cannot tell anyone, I cannot embarrass my family ... they would leave me (Margarida).

Those working with seropositive individuals, know that they hide bottles of anti -retroviral medication or change packs; they talk about their infection as it was another disease and search for help in distant cities with fear of being recognized. 
Hiding the disease was also demonstrated by not explaining children the real reason for taking medication.

When my son asks me the purpose of medication I keep quiet and force him to take the medication (Thaysa).

It was observed that mothers do not say anything to children and reaffirm imperatively that they must take the medication. Tension between what was said and not said regarding the use of medication and stating its intake as mandatory is constant in the speech of mothers and, for this reason, dialog is replaced by order leading to silence.

Even considering hiding as a denial and a normal stage of the relations with diseases and severe situations, the majority of seropositive individuals hide that they are infected, for as long as possible and in the best possible way ${ }^{(18)}$. With this, they try to avoid social isolation they could go through if they said they had HIV. Thus, fear of rejection and social discrimination makes those with HIV/AIDS try to hide diagnoses due to fear of the family reaction or of not being accepted in other social groups which they belong to ${ }^{(19)}$.

Considering that the family is the main source of support for seropositive, withdrawing from this contact may be harmful. In that, facing infection is a lonely process. Generally speaking, individuals develop beliefs that if they tell diagnoses they will not be accepted by their families, that they will be alone and abandoned and that they will embarrass their families.

In this sense, mothers and children survive a life marked by hiding, under the risk of social exposure to HIV, experiencing the possibility of stigmatization and prejudice.

- Resignation

Mothers taking part in the study tend to compare their children's disease with that from other children seropositive or not, and that present, at times, a more severe clinical picture. These comparisons occur during conversation between mothers in the waiting room of medical offices and outpatient clinics. These spaces enabled mothers, together with comparisons, an opportunity to exchange experience and talk about their emotions. Comparison of HIV children with other seropositive children makes some of them feel resigned. We may see this type of coping in the statement below:

... When I take my son to the doctor, there are other mothers with children there; then I can talk to them and I listen to so much suffering. I see children with HIV losing weight, with pneumonia, tuberculosis, and my son doesn't have any of this. I look at my son and I don't see anything, compared to what I see in other children. (Francisca).

Statements above show that mothers, when they compare their children with other children, observe that the others are in worse situations. This experience gave them a feeling of consolation, relief to suffering, because even with the disease, they could be worse.

These comparisons may be considered as positive and beneficial, because they make psychological adjustment of patients in risk situation easier. However, we must consider this statement carefully, because this situation may also make the severity of the disease clear, and give rise to feelings of hopelessness ${ }^{(20)}$.

- Religion and hope

Religious belief has been mentioned as a strategy used by interviewees to get used with seropositivity of their children. Spirituality, faith and beliefs give them the necessary strength for care and self-care so that they won't feel lonely in the struggle for life.

Religion is, therefore, a support, representing an important network of emotional support ${ }^{(21)}$. Faith in the divine is a way of explaining the world, overcoming and standing the existence, associating it with hope. (14)

The statement described below portraits this situation:

... I am holding God's hand; he follows me on this struggle and gives me strength. He is my partner when I am alone. I have faith in Jesus that the cure will come. After this dammed disease, I found God again (Bianca).

A study performed with seropositive women showed that religion was related to more active strategies for coping with the infection, in addition to being considered a greater source of social support ${ }^{(15)}$. Religious involvement was considered a reduction mechanism of the coping process of denial, and consequently prevention of psychological distress. Other studies also demonstrated religiosity as a source of support for mothers and pregnant women with HIV ${ }^{(22)}$. As a way to interpret life events, religion may represent support for coping with difficulties and change in attitude.

Hoping for a better future was seen as something positive, becoming a support force, that helped families avoid feeling discouraged and making them want to prolong life regardless of the situation. Families know there is no cure for AIDS, and understand that there is hope in a future free from the suffering imposed by the disease. 
The report described below confirms this situation:

I have hope that one day I'll see the cure of the disease, to see my son cured, and then everything will be beautiful again, I'll smile again, and then, I forget the cruel reality of living with this disease (Jane).

\section{FINAL CONSIDERATIONS}

This study showed that, despite difficulties and limitations imposed by HIV/AIDS, by its treatment and uncertainty in the current situation, mothers with HIV children, develop strategies that enabled coping and living better with the disease.

It was seen that among the several strategies reported, the following stand out: overprotection and fear; total dedication; denial; and underestimation of HIV; hiding the disease; comparison of child with other seropositive children; religion and hope.

Overprotection is a behavior resulting from the fear of children suffering violence and of the risk of developing opportunistic infections; total dedication reflects a way of alleviating guilty of mothers because they consider themselves responsible for transmitting the disease to their children; denial did not withdraw people from searching resources and attention, however, it minimized the pain; hiding is a way of coping with prejudice; resignation enabled to compare one's child with other HIV positive children, thus relieving suffering; and religion and hope appeared as a source of support.

Reaction to seropositivity and strategies used by individuals seem to be important factors that need to be considered to foster health and quality of life of our patients.

\section{REFERENCES}

1. Ministério da Saúde (BR). Aids. Boletim Epidemiológico. Brasília (DF): Ministério da Saúde; 2006.

2. Silveira EAA, Carvalho AMP. Familiares de clientes acometidos pelo HIV/AIDS e o atendimento prestado em uma unidade ambulatorial. Rev Latino-am Enfermagem 2002 novembro-dezembro; 6(10):813-8.

3. Souza AIJ, Silva KM, Silva M. Cuidando de familiares de crianças soropositivas no domicílio. Ciência, Cuidado e Saúde 2003 julho; 2(2):177-85.

4. Wiener LS, Vasquez MJP, Battles HB. Brief report: fathering a child living with HIV/AIDS: psychosocial adjustament and parenting stress. Journal of Pediatric Psychology 2001 september; 26(6): 353-8.

5. Brown LK, Lourie KJ. Children and adolescents living with HIV and AIDS: A review. Jo Child Psychol Psychiatry 2000 January; 41(1):81-96.

6. Bachanas PJ, Kullgren KA, Schwartz KS, McDaniel JS, Smith J, Nesheim S. Psychological adjustment in caregivers of schoolage children infected with HIV: stress, coping and family factors. J Pediat Psychol 2001 September; 26(6):331-42.

7. Bardin L. Análise de conteúdo. Lisboa: Edições 70; 1991. 8. Irvin $\mathrm{N}$, Klaus $\mathrm{MH}$, Kennel JH. Atendimento aos pais de um bebê com malformação congênita. In: Klaus $\mathrm{MH}$, Kennel JH. Pais/bebê: a formação do apego. Porto Alegre (RS): Artes Médicas; 1992. p. 170-244.

9. Bradford R. Children, families and chronic disease. Londres: Routledge; 1997.

10. Gazzinelli A. Convivendo com a doença crônica da criança: estratégias de enfrentamento. Rev Min Enferm 1997 julho; 1(1):13-20.

11. Guimarães R, Ferraz AF. A interface AIDS, estigma e identidade: Algumas considerações. Rev Min Enfermagem 2002 janeiro; 6(1/2):77-85.
12. Brasileiro M, Freitas MIF. Social representations about Aids in people over 50, infected by HIV. Rev Latino-am Enfermagem 2006 September-October ; 14(5):789-95.

13. Leitch DB. Mother-infant interaction: achieving synchrony. Nurs Res 1999; 49(1):55-8.

14. Neves LAS, Gir E. HIV positive mothers' beliefs about mother-to-child transmission. Rev Latino-am Enfermagem 2006 September-October; 14(5):781-8.

15. Prado G, Feaster DJ, Schwartz SJ, Pratt IA, Smith L, Szapocznik J. Religious involvement, coping, social support and psychological distress in HIV-soropositive African American mothers. AIDS Behav 2004 September; 8(3):221-35.

16. Kübler-ross E. AIDS: o desafio final. São Paulo (SP): Beste Seller; 1987.

17. Tunala $L$, Paiva V. Fatores psicossociais que dificultam a adesão de mulheres portadoras do HIV aos cuidadores de saúde. In: Teixeira PR organizador. Tá difícil de engolir? Experiências de adesão ao tratamento anti-retroviral em São Paulo. São Paulo (SP): Nepaids; 2000.

18. Lent C, Valle A. AIDS: sujeito e comunidade. São Paulo (SP): IDAC; 2000.

19. Ferraz $A F$, Stefanelli MC. Interações familiares de pessoas vivendo com HIV e AIDS. Rev Min Enferm 2001 janeiro; 5(1/ 2):52-59.

20. Small SP, Graydon JE. Uncertainty in hospitalized patients with chronic obstructive pulmonary disease. Int J Nurs Stud 1993; 30(3):239-46.

21. Faria JB de, Seidl EMF. Religiosidade, Enfrentamento e Bem-estar Subjetivo em pessoas vivendo com HIV/Aids. Psicol em Estudo 2006 janeiro/abril; 11(1):155-64.

22. Siegel K, Schrimshaw EW. Reasons and justifications for considering pregnancy among women living with HIV/AIDS. Psychol Women Q 2001 june; 25(2):112-23. 